\title{
Serotonin Exposure Improves Stress Resistance, Aggregation, and Biofilm Formation in the Probiotic Enterococcus faecium NCIMB10415
}

\author{
Rossella Scardaci $^{1}$, Marcello Manfredi ${ }^{2}$, Elettra Barberis ${ }^{2}$, Sara Scutera ${ }^{3}\left(\mathbb{D}\right.$, Emilio Marengo ${ }^{2}(\mathbb{D})$ and $^{2}$ \\ Enrica Pessione 1,*
}

\section{check for} updates

Citation: Scardaci, R.; Manfredi, M.; Barberis, E.; Scutera, S.; Marengo, E.; Pessione, E. Serotonin Exposure Improves Stress Resistance,

Aggregation, and Biofilm Formation in the Probiotic Enterococcus faecium NCIMB10415. Microbiol. Res. 2021, 12, 606-625. https://doi.org/10.3390/ microbiolres12030043

Academic Editor:

Ignazio Castagliuolo

Received: 18 May 2021

Accepted: 21 July 2021

Published: 26 July 2021

Publisher's Note: MDPI stays neutral with regard to jurisdictional claims in published maps and institutional affiliations.

Copyright: (c) 2021 by the authors. Licensee MDPI, Basel, Switzerland. This article is an open access article distributed under the terms and conditions of the Creative Commons Attribution (CC BY) license (https:// creativecommons.org/licenses/by/ $4.0 /)$.
1 Department of Life Sciences and Systems Biology, University of Torino, 10123 Torino, Italy; rossella.scardaci@unito.it

2 Department of Translational Medicine, Università del Piemonte Orientale, 28100 Novara, Italy; marcello.manfredi@uniupo.it (M.M.); elettra.barberis@uniupo.it (E.B.); emilio.marengo@uniupo.it (E.M.)

3 Department of Public Health and Pediatric Sciences, University of Torino, 10126 Torino, Italy; sara.scutera@unito.it

* Correspondence: enrica.pessione@unito.it

\begin{abstract}
The role of the microbiota-gut-brain axis in maintaining a healthy status is well recognized. In this bidirectional flux, the influence of host hormones on gut bacteria is crucial. However, data on commensal/probiotics are scarce since most reports analyzed the effects of human bioactive compounds on opportunistic strains, highlighting the risk of increased pathogenicity under stimulation. The present investigation examined the modifications induced by $5 \mathrm{HT}$, a tryptophan-derived molecule abundant in the intestine, on the probiotic Enterococcus faecium NCIMB10415. Specific phenotypic modifications concerning the probiotic potential and possible effects of treated bacteria on dendritic cells were explored together with the comparative soluble proteome evaluation. Increased resistance to bile salts and ampicillin in 5HT-stimulated conditions relate with overexpression of specific proteins (among which Zn-beta-lactamases, a Zn-transport protein and a protein involved in fatty acid incorporation into the membrane). Better auto-aggregating properties and biofilm-forming aptitude are consistent with enhanced QS peptide transport. Concerning interaction with the host, E. faecium NCIMB10415 enhanced dendritic cell maturation, but no significant differences were observed between 5HT-treated and untreated bacteria; meanwhile, after 5HT exposure, some moonlight proteins possibly involved in tissue adhesion were found in higher abundance. Finally, the finding in stimulated conditions of a higher abundance of $\mathrm{VicR}$, a protein involved in two-component signal transduction system (VicK/R), suggests the existence of a possible surface receptor (VicK) for 5HT sensing in the strain studied. These overall data indicate that E. faecium NCIMB10415 modifies its physiology in response to $5 \mathrm{HT}$ by improving bacterial interactions and resistance to stressors.
\end{abstract}

Keywords: microbiota-gut-brain axis; stationary phase growth; ampicillin resistance; bile salt tolerance; gel-free proteomics; moonlight proteins; two-component systems

\section{Introduction}

The cross-talk between enteric bacteria and the human host often occurs by means of shared molecules that support reciprocal physiological regulation [1]. It is now clear that a common language exists between phylogenetically very distant organisms and some informational molecules that were conserved during evolution, are present in "brainless" organisms such as bacteria, where they generally perform a different function [2]. In the context of this bidirectional regulation, a bottom-up effect has been described, where host physiological functions such as immunity, appetite, sleep, and mood can be controlled by bacterial-derived molecules $[3,4]$. Some examples regard bacteria as able to produce brain-targeting neuroactive compounds such as gamma-amino butyric acid $[5,6]$ 
dopamine and nor-epinephrine [7], melatonin [8], indole, similar to melatonin [9], a muramyl dipeptide similar to serotonin [10], and serotonin (5HT) [11]. In parallel, bacterial traits such as pathogenicity, toxin production, ability to form biofilm and to aggregate, as well as to tolerate stressing conditions can be modulated by host-derived compounds by a top-down control system [12,13]. In particular, prokaryotes, especially pathogenic bacteria, can respond to host-derived compounds such as dopamine [14], norepinephrine (NE) [15,16], epinephrine [17], melatonin [18], and 5HT [19], often by enhancing their pathogenic potential.

The importance of tryptophan and its metabolites in the microbiota gut-brain-axis has been highlighted in the works of O'Mahony [20] and Galligan [21]. This amino acid can be directly synthesized by enteric bacteria possessing tryptophan synthase [22,23], or can derive from food. Therefore, its availability depends on the microbiota composition and the diet. In addition, it can be channeled in different metabolic pathways by gut bacteria, among which the most important are those generating indole, 5HT, and melatonin [24]. In particular, $5 \mathrm{HT}$ can be produced from tryptophan by different bacterial genera, including Morganella, Klebsiella [11], and lactic acid bacteria (LAB) (Streptococcus, Lactobacillus, and Lactococcus) $[25,26]$, and also by enteroendocrine (EEC) and enterochromaffin cells (ECC) in the human gut mucosa by using both diet-derived and microbial synthesized tryptophan.

On the other hand, it must be underlined that $90 \%$ of human $5 \mathrm{HT}$ is produced in the gut, where it is involved in GI motility, secretion, and initiation of vagal and nociceptive reflexes through the activation of diverse families of 5-HT receptors. Moreover, alterations in 5HT signaling in the gut have been linked to the pathophysiology of several GI disorders [27].

In this context, it is of high interest to evaluate how bacteria can respond to changes in the gut environment due to sudden increase of 5HT. In the literature, data on the biological effects of this molecule on prokaryotes are scarce in comparison with other hormones (i.e., epinephrine and NE), and most reports concern only pathogenic bacteria [19,28].

In the present work, we take into consideration the effects exerted by $5 \mathrm{HT}$ on a particular commensal/probiotic strain of LAB, E. faecium NCIMB10415. Most Enterococci belonging to human microbiota display beneficial features, and therefore could be classified among probiotics. However, for the Enterococcus genus, some controversial behavior is reported concerning virulence factors, production, and antibiotic resistance [29]. These unwanted characters could be modulated by external environmental factors; therefore, it is of high importance to assess safety in every pathophysiological condition that may occur in the human gut. Analyses of some phenotypic traits, such as growth rates, auto-aggregation, biofilm formation, resistance to bile salts, and antibiotic response profiles, evaluated in stimulated and control conditions, revealed that 5HT can alter E. faecium NCIMB10415 physiology. Furthermore, the gel-free proteomic results are consistent with the observed modifications, also indicating the presence of a receptor-like protein for serotonin in this bacterial strain.

\section{Materials and Methods}

\subsection{Bacterial Strain and Growth Conditions}

E. faecium NCIMB 10415 , isolated from a probiotic preparation, was stocked at $-20{ }^{\circ} \mathrm{C}$ in $25 \%$ glycerol. A rich chemically defined medium (CDM) [30,31] at pH 7 was selected for culturing bacteria in control condition and treated with serotonin (serotonin hydrochloride, Sigma-Aldrich Inc., St. Louis, MO, USA) in order to avoid the differences between commercial batches and to easily replicate the exact composition in the laboratory, weighing every nutrient. The components of CDM are presented in Supplementary Materials and Methods (SM1). Brain heart infusion (BHI, (Sigma-Aldrich Inc., St. Louis, MO, USA) supplemented with $1.5 \%$ agar was used as solid medium (BHI/A,Sigma-Aldrich Inc., St. Louis, MO, USA). 5HT was freshly dissolved in CDM, filter sterilized, and diluted accordingly to the experiments. 


\subsection{Growth Kinetics}

Growth kinetics were recorded in a multiplate reader (Filtermax F5) comparing the control curves in CDM to the treatments with multiple concentrations of 5HT in CDM $(0.5 \mathrm{nM}, 500 \mathrm{nM}, 0.5 \mu \mathrm{M}, 50 \mu \mathrm{M}, 500 \mu \mathrm{M})$. Orbital shaking and reading $\mathrm{OD}_{595}$ every $30 \mathrm{~min}$ for $24 \mathrm{~h}$ at $37^{\circ} \mathrm{C}$ were the parameters chosen for the experiments. Each concentration was tested for 10 different wells, and the test was repeated three independent times. The error bars for each point of the curve correspond to the standard error for each set of measurements. The growth rates $(\mu)$ were calculated and expressed as $\%$ of the control \pm standard deviation.

\subsection{Phenotypic Evaluations}

\subsubsection{Resistance to Bile Salts}

To test the resistance to bile salts, $1 \mathrm{~mL}$ of late exponential phase E. faecium culture $(\approx 4 \mathrm{~h}$ of growth), treated with $50 \mu \mathrm{M} 5 \mathrm{HT}$ or in control condition, was harvested by centrifugation $(10,000 \times g, 10 \mathrm{~min}, \mathrm{RT})$ and the pellets were suspended in fresh CDM supplemented with $4.5 \%$ bile salts and no $5 \mathrm{HT}$ (bile, bovine, Sigma-Aldrich Inc., St. Louis, $\mathrm{MO}$, USA). Then, the bacteria were incubated at $37^{\circ} \mathrm{C}$, for $4 \mathrm{~h}$ and $100 \mathrm{rpm}$, to mimic the intestine transit. The samples collected at $\mathrm{T} 0$ and $\mathrm{T} 4$ were diluted in $0.9 \% \mathrm{NaCl}$ and counted on BHI/A after $24 \mathrm{~h}, 37^{\circ} \mathrm{C}$. The bile salt tolerance (BST) was calculated as a survival rate (SR): $\left[\mathrm{CFU} / \mathrm{mL} \mathrm{T}_{4}\right] /\left[\mathrm{CFU} / \mathrm{mL} \mathrm{T}_{0}\right] \times 100$ [32], and the results are expressed as $\%$ of control.

\subsubsection{Auto-Aggregation}

The auto-aggregation in control bacteria and in presence of 5HT was executed as described previously [33] with some modifications. Concisely, cultures grown until the late exponential phase $(4 \mathrm{~h})$ were centrifuged $\left(10,000 \times g, 10 \mathrm{~min}^{\prime}, \mathrm{RT}\right)$ and suspended in $\mathrm{NaCl}$ $0.9 \%$. Bacteria were then diluted to reach an $\mathrm{OD}_{600}$ of about 0.3 , and $1 \mathrm{~mL}$ was distributed in 10 sterile cuvettes. $\mathrm{OD}_{600}$ was measured at $\mathrm{T}_{0}\left(\mathrm{OD}_{0}\right)$ and after $2 \mathrm{~h}$ at $37^{\circ} \mathrm{C}\left(\mathrm{OD}_{2}\right)$ straight into the cuvette. The auto-aggregation percentage was determined with the following formula: $\left[1-\left(\mathrm{OD}_{2} / \mathrm{OD}_{0}\right) \times 100\right]$. The results are a mean of three different experiments performed in three independent days.

\subsubsection{Biofilm Formation}

Whether the presence of $5 \mathrm{HT}$ might have influenced the formation of biofilm biomasses was investigated with the crystal violet method [34], with slight modifications. O/N precultures were diluted to an $\mathrm{OD}_{600} 0.4$ with or without $5 \mathrm{HT}$ in a 96-well plate and let to grow for 24 or $48 \mathrm{~h}$ at $37^{\circ} \mathrm{C}$, in the latter case with medium and molecule replacement after the first $24 \mathrm{~h}$. At the end of the incubation period, planktonic cells were removed, and the plate was washed three times with MilliQ water. Cells were stained with $150 \mu \mathrm{L}$ of $0.1 \%$ crystal violet (PanReac-AppliChem ITW Reagents, Glenview, IL, USA) for 15min at RT, the plate was then rinsed three times with MilliQ and let to dry perfectly at $37^{\circ} \mathrm{C} ; 150 \mu \mathrm{L}$ of $99 \% \mathrm{EtOH}$ was used to extract the crystal violet and the $\mathrm{A}_{595}$ was measured (Filtermax F5). Results are expressed as percentages of control: $\left(\mathrm{A}_{595} 5 \mathrm{HT}\right) /\left(\mathrm{A}_{595} \mathrm{C}\right) \times 100$.

\subsubsection{Antibiotic Susceptibility Test}

The possible modifications in the susceptibility to ampicillin (Amp) and vancomycin (Van) induced by $5 \mathrm{HT}$ on our strain were investigated by means of the E-test system (Estrip, BioMérieux Inc., St. Louis, MO, USA). Briefly, bacteria cultured in control condition and with $5 \mathrm{HT}$ were harvested at the early stationary phase, $100 \mu \mathrm{L}$ of cultures were then spread on $\mathrm{BHI} / \mathrm{A}$ and the antimicrobial agent strips were applied to the plates. After incubation $\left(\mathrm{O} / \mathrm{N}, 37^{\circ} \mathrm{C}\right)$, a zone of growth inhibition was seen around the plates, and the minimal inhibitory concentration (MIC) was read from the scale on the strip. 


\subsection{Whole Cell Proteomic Analyses}

\subsubsection{Soluble Proteins Extraction}

A volume of culture corresponding to $50 \mathrm{mg}$ of dry weight of cells was collected in late exponential phase ( $4 \mathrm{~h}$ of growth) by centrifugation at $4000 \times \mathrm{g}$ for $20 \mathrm{~min}$ at $4{ }^{\circ} \mathrm{C}$, for each sample of control and $50 \mu \mathrm{M}$ 5HT-treated bacteria. Pellets were washed twice with $\mathrm{NaCl} 0.9 \%$ and resuspended in $3 \mathrm{~mL}$ of Tris- $\mathrm{HCl} 50 \mathrm{mM}, 1 \mathrm{mM}$ EDTA, pH 7.3, and sonicated on ice for $30 \mathrm{~min}$ at $20 \mathrm{KHz}$ with intervals of $20 \mathrm{~s}$. To obtain the highest amount of proteins, the unbroken cells were recovered by centrifugation at $4000 \times g$ for $20 \mathrm{~min}$ at $4{ }^{\circ} \mathrm{C}$, and the procedure was repeated on the pellets [35]. Six milliliters of supernatant was then ultracentrifuged at $18,000 \times \mathrm{g}$ for $45 \mathrm{~min}$ at $4{ }^{\circ} \mathrm{C}$ in a Beckman L8-60M Ultracentrifuge, Ti60 rotor [36]. Proteins were precipitated with chloroform and methanol according to Wessels and Flügge [37]. The pellet containing only proteins was resuspended in $500 \mu \mathrm{L}$ of solution containing $50 \mathrm{mM} \mathrm{NH}_{4} \mathrm{HCO}_{3}$. The protein quantification was assessed by 2-D Quant kit (GE Healthcare, Little Chalfont, Buckinghamshire, UK). The protein samples were collected from three biological replicates.

\subsubsection{In-Solution Protein Digestion}

Prior to SWATH-MS (sequential window acquisition of all theoretical fragment ion spectra mass spectrometry) [38,39], proteins were digested in trypsin. An amount of $100 \mu \mathrm{g}$ of protein in $25 \mu \mathrm{L}$ of $100 \mathrm{mM} \mathrm{NH}_{4} \mathrm{HCO}_{3}$ was reduced with $2.5 \mu \mathrm{L}$ of $200 \mathrm{mM}$ DTT (SigmaAldrich Inc., St. Louis, MO, USA) at $90^{\circ} \mathrm{C}$ for $20 \mathrm{~min}$ and next alkylated with $10 \mu \mathrm{L} 200 \mathrm{mM}$ iodoacetamide (Sigma-Aldrich Inc., St. Louis, MO, USA) for $1 \mathrm{~h}$ at RT and protected from light. Any excess of iodoacetamide was removed by the addition of $200 \mathrm{mM}$ DTT [40]. The samples were then diluted with $300 \mu \mathrm{L}$ of MilliQ and $100 \mu \mathrm{L}$ of $100 \mathrm{mM} \mathrm{NH}_{4} \mathrm{HCO}_{3}$ to raise the $\mathrm{pH}$ to $7.5 / 8$, and $5 \mu \mathrm{g}$ of trypsin (Promega, Madison, WI, USA, Sequence Grade) was added. After an $\mathrm{ON}$ incubation at $37^{\circ} \mathrm{C}, 2 \mu \mathrm{L}$ of neat formic acid stopped the trypsin activity and digests were dried by speed vacuum [41]. The peptide digests were desalted on the Discovery ${ }^{\circledR}$ DSC-18 solid phase extraction (SPE) 96-well plate (25 mg/well) (Sigma-Aldrich Inc., St. Louis, MO, USA) as reported elsewhere [42].

\subsubsection{SWATH-MS Analysis}

LC-MS/MS was executed on a micro-LC Eksigent Technologies (Dublin, CA, USA) system, using the Halo Fused C18 column $(0.5 \times 100$ mm, $2.7 \mu \mathrm{m}$; Eksigent Technologies, Dublin, CA, USA) as stationary phase. A volume of $4.0 \mu \mathrm{L}$ was injected every time and the oven temperature was $40{ }^{\circ} \mathrm{C} .0 .1 \%(v / v)$ formic acid in water $(\mathrm{A})$ and $0.1 \%(v / v)$ formic acid in acetonitrile (B) were mixed at increasing concentrations of B from $2 \%$ to $40 \%$ eluting at a flow rate of $15.0 \mu \mathrm{L} / \mathrm{min}$ for $30 \mathrm{~min}$. A 5600+ TripleTOF system (AB Sciex, Concord, ON, Canada) equipped with a DuoSpray Ion Source and CDS (calibrant delivery system) was put at the interface with the LC system. The samples utilized to produce the SWATH-MS spectral library were the first object of the traditional data-dependent acquisition (DDA) and afterwards, for the label-free quantification of the cyclic data independent analysis (DIA) of the mass spectra, as previously described [43]. The MS data were acquired with Analyst TF 1.7 (SCIEX, Concord, ON, Canada). Three instrumental replicates for each of the three biological replicates were subjected to the DIA analysis [44].

\subsubsection{Protein Data Search}

The software Protein Pilot v. 4.2 (SCIEX, Concord, Vaughan, ON, Canada) was used to search the MS files. Cysteine alkylation, digestion by trypsin, no special factors, and false discovery rate at $1 \%$ were set up as parameters. The files were additionally examined with Mascot v. 2.4 (Matrix Science Inc., Boston, MA, USA) using trypsin as enzyme, 2 missed cleavages, and a search tolerance of $50 \mathrm{ppm}$ set for the peptide mass tolerance, 0.1 Da for the MS/MS tolerance, charges of peptides to search for were specified with $2+$, $3+$, and $4+$, and the search was set on monoisotopic mass. The instrument was set to ESI-QUAD-TOF and the modifications for the search were set as follows: carbamidomethyl 
cysteines as fixed modification and oxidized methionine as the variable one. The DIA files were subsequently switched to pseudo-MS/MS spectra by the DIA-Umpire software and were searched as DDA files on Mascot and Protein Pilot using the same parameters used for the DDA search. The UniProt/Swiss-Prot reviewed database containing E. faecium proteins (NCBI_Enterococcus_Faecium, version 01042019, 12110 sequence entries) was utilized.

\subsubsection{Protein Quantification}

PeakView 2.0 and MarkerView 1.2. (Sciex, Concord, ON, Canada) were used to obtain a label-free quantification of the ion chromatograms of all unique ions for the resulting peptides. The DDA acquisitions and a protein FDR threshold of $1 \%$ were utilized to build an integrated assay library. Six transitions per peptide and six peptides per protein were extracted from the SWATH files, excluding peptides with modifications and shared peptides. $T$-test was performed on peptides with FDR $<1 \%$ exported in MarkerView. A $p$-value $<0.05$ and fold change $>1.3$ were selected as maximum values to choose proteins with lower or higher abundance. The data concerning the mass spectrometry proteomics, with the dataset identifier PXD023456, are deposited in the ProteomeXchange Consortium by the PRIDE [45] partner repository (https://www.ebi.ac.uk/pride/archive/, accessed on 7 January 2021).

\subsubsection{Protein Classification}

All the annotated proteins differentially abundant in the two conditions were analyzed using the UniProt/Swiss-Prot reviewed database (https: / / www.uniprot.org/, accessed on 7 January 2021) and the eggNOG database of orthologous groups and functional annotation (http:/ / eggnogdb.embl.de/\#/app/home, accessed on 7 January 2021). Clusters of orthologous groups (COGs) of proteins are provided by the eggNOG resource [46] that represents the base of a functional protein classification based on precisely deciphered evolutionary relationships [47].

\subsection{Immune-Stimulating Activity of Killed E. faecium NCIMB 104145 Cells and Cell Free Supernatants}

2.5.1. Preparation of the Bacterial Strain and Cell-Free Culture Supernatant for Dendritic Cells (DC) Maturation Assays

E. faecium NO SPACENCIMB104145 was cultured in the presence or absence of $50 \mu \mathrm{M} 5 \mathrm{HT}$ at $37{ }^{\circ} \mathrm{C}$ for $4 \mathrm{~h}$ (late exponential phase). Bacterial cells were harvested by centrifugation $(12,000 \times g, 10 \mathrm{~min}, \mathrm{RT})$, washed twice in sterile PBS and resuspended in the same buffer. For the preparation of the heat-killed (HK) samples, bacterial cells were heated for $30 \mathrm{~min}$ at $90^{\circ} \mathrm{C}$. Complete loss of cell viability was verified by monitoring colony formation on agar plate.

\subsubsection{Monocyte-Derived DC Preparation}

Monocytes were isolated from peripheral blood mononuclear cells obtained from healthy donor buffy coats (through the courtesy of the S.C. Centro Produzione e Validazione Emocomponenti, Torino) by immunomagnetic selection with CD14 microbeads (MACS monocyte isolation kit from Miltenyi Biotec, Bergisch Gladbach, Germany). This procedure yields a greater than $98 \%$ pure monocyte population, as assessed by fluorescence-activated cell sorter analysis (FACSCalibur, BD Biosciences, Franklin Lakes, NJ, USA). To obtain monocyte-derived DCs, monocytes were cultured for 5 days at $10^{6}$ cells $/ \mathrm{mL}$ in RPMI 1640 medium (Gibco Thermo Fisher Scientific, Waltham, MA, USA) containing 10\% FCS in the presence of GM-CSF (50 ng/mL) and IL-4 (20 ng/mL) (both from PeproTech, Rocky Hill, NJ, USA).

\subsubsection{Monocyte-Derived DC Stimulation}

Immature DC were seeded at the density of $1 \times 10^{6} / \mathrm{mL}$ and incubated with HK Enterococcus faecium NCIMB 10415 (bacteria/host ratio 10:1), with CSF added to the DC 
culture medium at a concentration of 10-30\% v/v and LPS (100 ng/mL) for $40 \mathrm{~h}$. Cells and cell supernatants were collected for flow cytometric and cytokine analysis.

\subsubsection{Flow Cytometric Analysis}

DC were acquired with a FACSCalibur and analyzed using Flowlogic software (Miltenyi Biotec, Bergisch Gladbach, Germany), using the following antibodies: anti CD80-PE, anti CD-83-VioFITC, and the corresponding isotype control antibodies (all purchased from Miltenyi Biotec, Bergisch Gladbach, Germany).

\subsection{Statistical Analyses}

Data collected from a minimum of three experiments are expressed as mean \pm standard error (SEM) and statistical significance assessed using Student's $t$-test using the software GraphPad Prism 6.

\section{Results}

The possible physiological modifications occurring in E. faecium NCIMB10415 after treatment with 5HT were assessed with references to the soluble proteomic profiles. Then, the effect of HK treated and untreated enterococci on DC was investigated to elucidate possible feedback modulations on human immune cells due to 5HT stimulation of the bacterial strain.

\subsection{Growth Kinetics}

Figure 1 illustrates the growth curves of E. faecium NCIMB10415 stimulated with different doses of $5 \mathrm{HT}(0.5 \mathrm{nM}, 50 \mathrm{nM}, 500 \mathrm{nM}, 50 \mu \mathrm{M}$, and $500 \mu \mathrm{M})$ including control conditions (no 5HT). Higher $\mathrm{OD}_{595}$ values after treatments with all the different concentrations of the molecule are perceivable since the beginning of the stationary phase $(\approx 4 \mathrm{~h}$ of growth), but the difference becomes more evident during the middle and late stationary phase (namely after $15 \mathrm{~h}$ of growth). Precisely, the $\mathrm{OD}_{595}$ at $24 \mathrm{~h}$ for the $0.5 \mathrm{nM}, 50 \mathrm{nM}, 500 \mathrm{nM}, 50 \mu \mathrm{M}$, and $500 \mu \mathrm{M}$ treatments are $1.0 \pm 0.13,1.1 \pm 0.11,1.3 \pm 0.12,1.2 \pm 0.01$, and $1.1 \pm 0.02$-fold greater than untreated controls, respectively (SM3). SM3 also presents the CFU counting at $24 \mathrm{~h}$ for each concentration of 5HT. The growth rates $(\mu)$, expressed in percentage of control, are only slightly increased by the hormone and are in order: $103.2 \pm 1 \%, 104.3$ $\pm 1.3 \%, 104.9 \pm 0.5 \%, 103.6 \pm 1.5 \%$, and $101.3 \pm 0.8 \%$. Among all, the concentration of $50 \mu \mathrm{M} 5 \mathrm{HT}$ was selected to treat E. faecium NCIMB10415 for the successive studies, as justified in the following paragraphs.

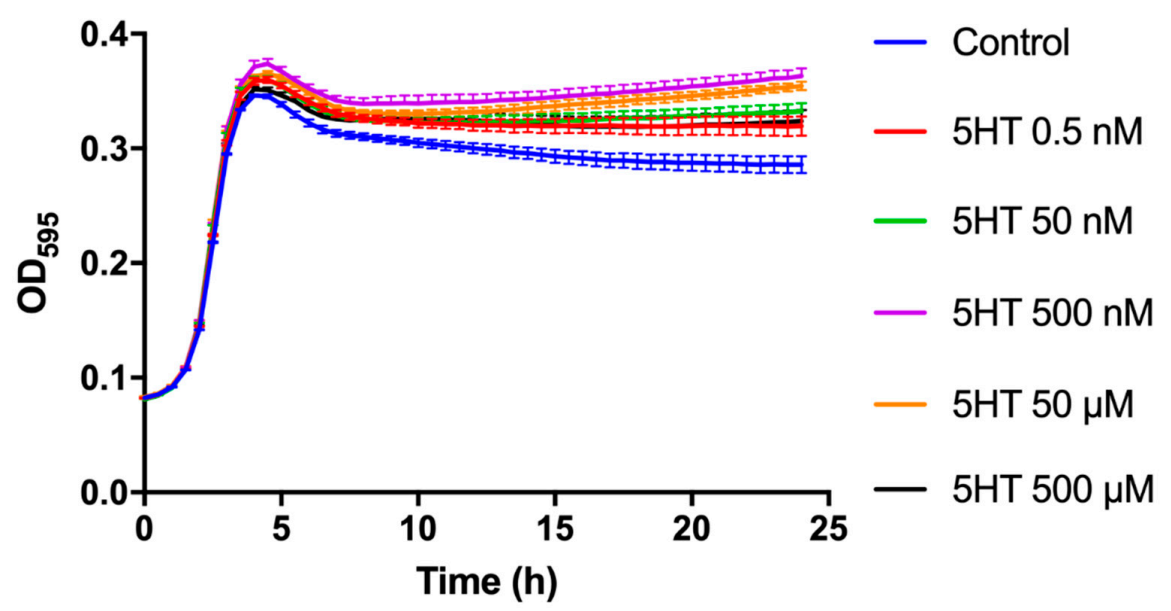

Figure 1. Growth changes. Growth kinetics of $24 \mathrm{~h}$ : effect of different concentrations of $5 \mathrm{HT}(0.5 \mathrm{nM}$, $50 \mathrm{nM}, 500 \mathrm{nM}, 50 \mu \mathrm{M}, 500 \mu \mathrm{M}$ ) on the growth of E. faecium NCIMB10415. The effect of the molecule is detectable during the mid and late stationary phase. 


\subsection{Phenotypic Evaluations}

\subsubsection{Bile Salt Resistance}

We investigated if 5HT treatment could modify the ability of E. faecium NCIMB10415 to tolerate the surfactant and membrane-damaging activity of bile salts by comparing the final cell number of 5HT-exposed and unexposed bacteria and calculating the BST. In Figure 2, the results obtained clearly indicate that $50 \mu \mathrm{M} 5 \mathrm{HT}$ treatment increased our strain's rate of survival of approximately $40 \%$.

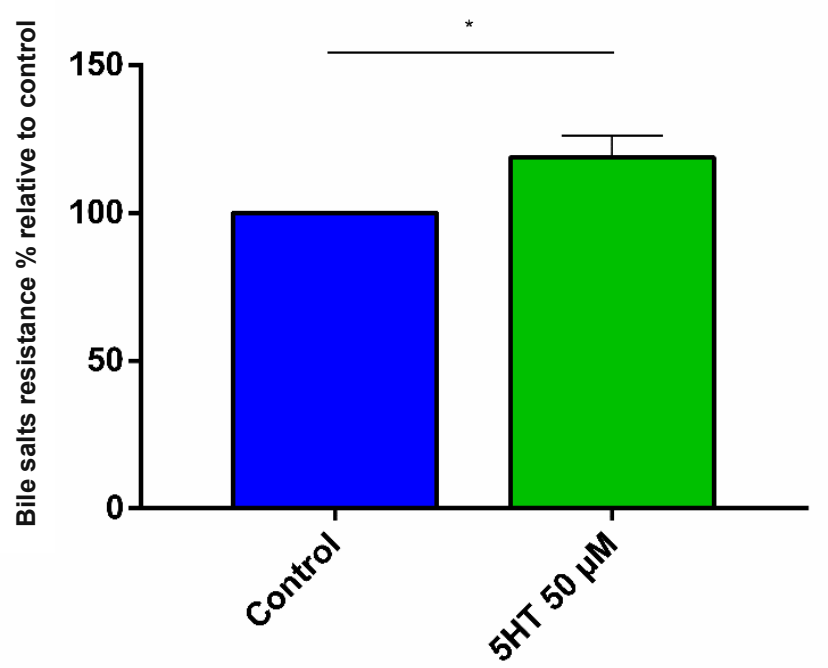

Figure 2. Bile salt resistance. Bile salts (4.5\%) tolerance of E. faecium NCIMB10415 is expressed as \% of control and is increased after a pre-treatment with $50 \mu \mathrm{M} 5 \mathrm{HT}\left({ }^{*} p<0.05\right)$.

\subsubsection{Auto-Aggregation Assay}

Bacterial auto-aggregation, as an index of good gut colonization ability, was evaluated. The results reported in Figure 3 reveal an increased auto-aggregation capability of E. faecium NCIMB10415 $(+25 \%)$ when treated with 5HT; precisely, the percentages of auto-aggregation were $9.6 \pm 0.6$ for the control and $12.1 \pm 0.8$ for the treated samples.

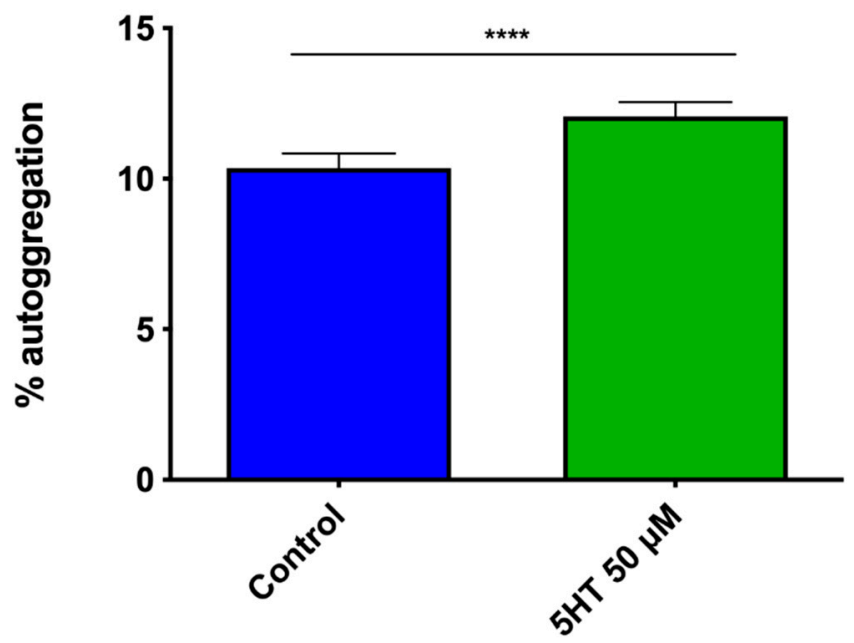

Figure 3. Auto-aggregation. Percent auto-aggregation of E. faecium NCIMB10415 is enhanced after the treatment with $50 \mu \mathrm{M} 5 \mathrm{HT}\left({ }^{* * * *} p<0.0001\right)$ compared to the control condition.

\subsubsection{Biofilm Formation}

The aptitude of bacteria to persist in the gut environment, measured as biofilmforming tendency, was tested in stimulated and control conditions. Here, we examined 
how the exposure to $50 \mu \mathrm{M} 5 \mathrm{HT}$ could affect the capability of E. faecium NCIMB10415 to form biofilm after 24 and $48 \mathrm{~h}$ of incubation. The difference in the biofilm biomasses of exposed and unexposed bacteria after the first $24 \mathrm{~h}$ of incubation is undetectable (Figure $4 \mathrm{~A}$ ), whereas it is clear and relevant at the end of the $48 \mathrm{~h}$, after the removal of the old CDM and the addition of fresh medium and 5HT (Figure 4B). As represented in the bar chart, a 20\% biofilm biomass enhancement after $48 \mathrm{~h}$ is detectable in the cultures stimulated with the human hormone compared to the control condition.
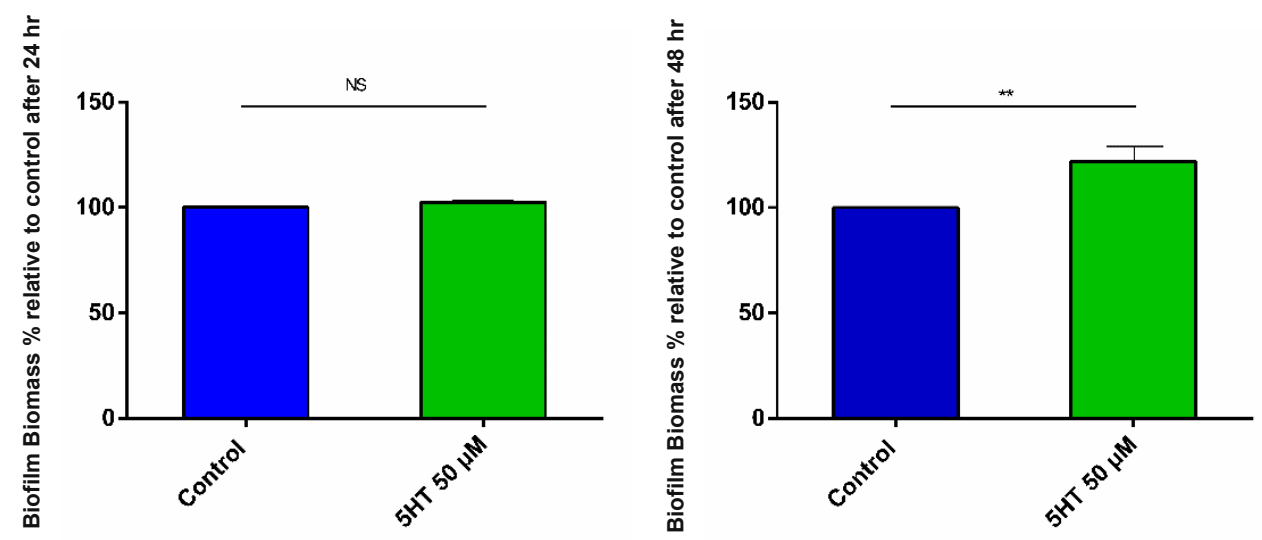

Figure 4. Biofilm. Biofilm biomass formation revealed with the crystal violet staining method, after the treatment of $E$. faecium NCIMB10415 with $50 \mu \mathrm{M} 5 \mathrm{HT}$ for $24 \mathrm{~h}$ or $48 \mathrm{~h}$, and expressed in \% of control. The stimulating effect of $5 \mathrm{HT}$ is detectable only after $48 \mathrm{~h}$ of growth (NS: not significant, ${ }^{* *} p<0.01$ ).

\subsubsection{Antibiotic Susceptibility}

The antibiotic susceptibility test was intended to measure whether the pretreatment with 5HT could affect the susceptibility of E. faecium NCIMB10415 to Amp and Van. The MIC increased almost $50 \%$ for Amp $(0.38 \pm 0.00 \mu \mathrm{g} / \mathrm{mL}$ for control, $0.56 \pm 0.10 \mu \mathrm{g} / \mathrm{mL}$ for 5 HT treated) as reported in Table 1, while the variation in MIC for Van was not significant.

Table 1. Antibiotic susceptibility. E. faecium NCIMB10415 treated with $50 \mu \mathrm{M} 5 \mathrm{HT}$ modifies its sensitivity to Amp relative to control condition $(* * p<0.01)$ but not to Van (ns: not significant).

\begin{tabular}{ccc}
\hline Treatment & MIC Amp $(\mu \mathrm{g} / \mathrm{mL})$ & MIC Van $(\mu \mathrm{g} / \mathrm{mL})$ \\
\hline Control & $0.38 \pm 0.0$ & $1.1 \pm 0.3$ \\
\hline 5HT $50 \mu \mathrm{M}$ & $0.56 \pm 0.1^{* *}$ & $1.0 \pm 0.3^{\mathrm{ns}}$ \\
\hline
\end{tabular}

\subsection{Whole Cell Proteomic Analyses}

SWATH-MS approach was utilized in order to identify possible 5HT-induced proteins or differently abundant housekeeping enzymes, combining high levels of protein recovery and reproducible data [38,39]. The analyses lead to the identification of 690 of the annotated proteins [48], listed in Supplementary Material 2 (SM2), and 45 were found as statistically differently abundant ( $p$-value $<0.05$ ), being at least 1.3 -fold higher in one condition compared to the other. Only the $20 \%$ of these proteins showed a lower abundance after $5 \mathrm{HT}$ treatment, while $80 \%$ were more abundant. The COGs and the UniProt/SwissProt reviewed database (www.uniprot.com, accessed on 7 January 2021) were utilized to assess and examine their biological functions so that the most notable proteins identified were divided in six functional categories, reported in Figure 5. Signal transduction (vicR, HMPREF0351_12362, fold change 1.4; MCP, HMPREF0351_12008, fold change 1.5; gdhA, HMPREF0351_11739 fold change 1.4). DNA replication (dnaN, HMPREF0351_10002, fold change 1.4; HMPREF0351_10671, fold change 1.5) and Nucleic acids metabolism (thiD, HMPREF0351_11067, fold change 1.6). Transport systems (HMPREF0351_11100, fold change 
2.1; brnQ, HMPREF0351_10149, fold change 1.9; HMPREF0351_12100, fold change 2.2; HMPREF0351_12278 fold change 1.5; oppF, HMPREF0351_10097, fold change 1.3), moonlight proteins (arcB, HMPREF0351_11693, fold change 1.4; pdhA, HMPREF0351_11225, fold change 1.6; HMPREF0351_10049, fold change 2.4), stress/stress counteracting proteins (HMPREF0351_10014, fold change 2.2; uspA, HMPREF0351_10246, fold change 1.3; HMPREF0351_12544, fold change 2; HMPREF0351_10245, fold change 1.5), and proteins involved in resistance to antibiotics (HMPREF0351_10757, fold change 1.8; ppiA, HMPREF0351_10611, fold change 0.7).

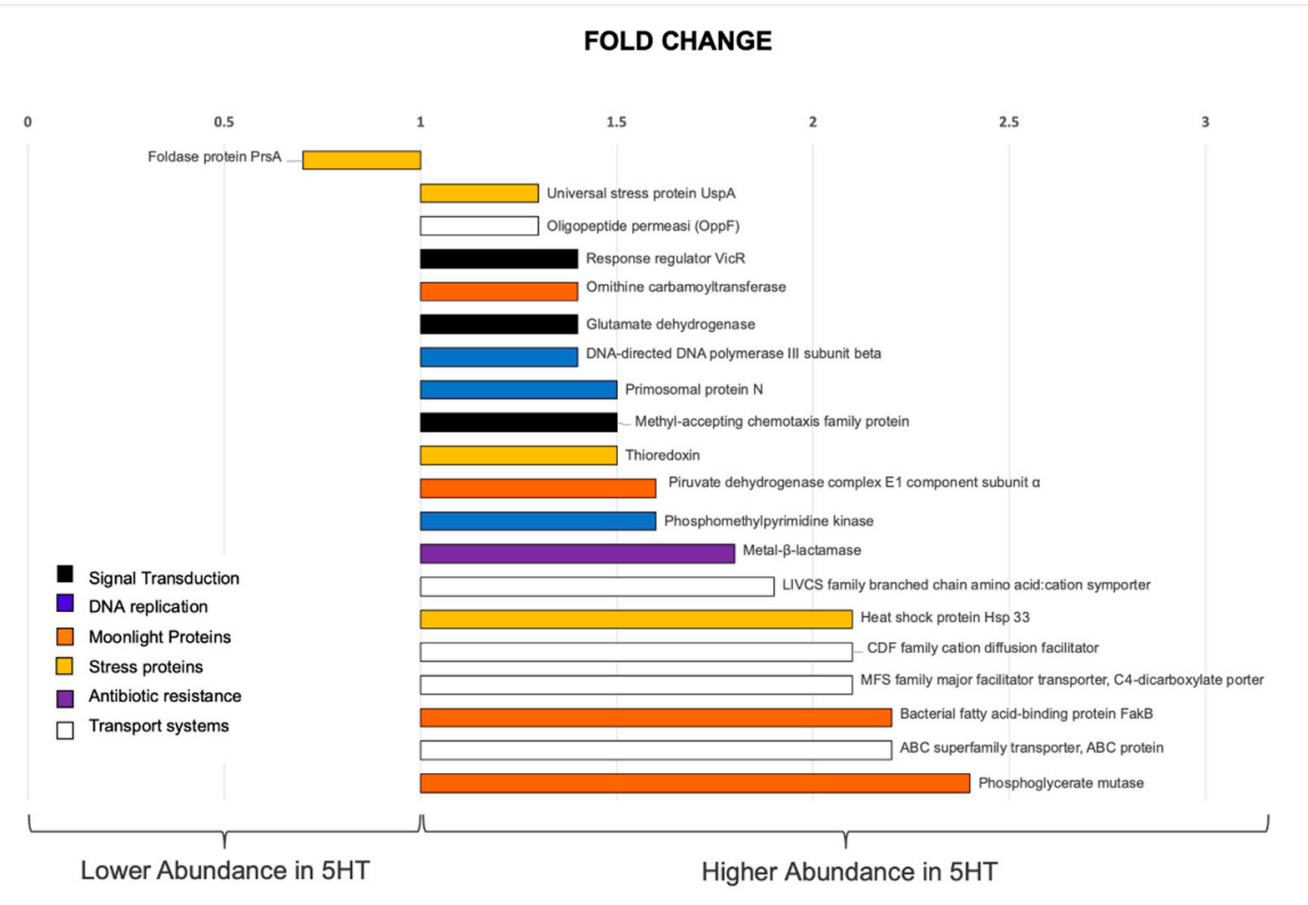

Figure 5. Proteomic relevant results. The bar chart shows the proteins with different abundance in $50 \mu \mathrm{M}$ 5HT-treated E. faecium NCIMB 10415 compared to control condition ( $p$-value $\leq 0.05$ ) and ordered by fold change. The proteins are divided in six main categories (signal transduction, DNA replication, moonlighting proteins, stress response proteins, proteins devoted to membrane transport, and to antibiotic resistance). On the left, the peptidyl-prolyl isomerase protein PrsA is displayed in lower abundance, while on the right, all the proteins with higher abundance in 5HT are presented. They are in order: Universal stress protein UspA, Oligopeptide permease (OppF), Response regulator VicR, Ornithine carbamoyltransferase, Glutamate dehydrogenase, DNA-directed DNA polymerase III subunit beta, Primosomal protein N, Methyl-accepting chemotaxis family protein, Thioredoxin, Piruvate dehydrogenase complex E1 component subunit $\alpha$, Phosphomethylpyrimidine kinase, Metal$\beta$-lactamase, LIVCS family branched chain amino acid: cation symporter, Heat shock protein Hsp 33, CDF family cation diffusion facilitator, MFS family major facilitator transporter, C4-dicarboxylate porter, FakB bacterial fatty acid-binding protein, and an ABC superfamily transporter.

\subsection{HT Treated and Control E. faecium NCIMB10415 Effects on DC Maturation}

We analyzed whether living cells of E. faecium NCIMB10415 untreated or treated with $50 \mu \mathrm{M} 5 \mathrm{HT}$ differentially modulated the expression of maturation markers in DCs. We analyzed the CD80 and CD83 expression in terms of mean fluorescence intensity (MFI) using LPS as a positive control for DC maturation. The experiment performed with living cells was unsuccessful probably because the acidification produced during enterococcal lactic fermentation damaged the DC. Therefore, we decided to use heath killed (HK) enterococcal cells. The DC were incubated with HKE, HKE/5HT, and LPS, and evaluated for the expression of CD80 and CD83 as activation/maturation markers. We observed 
an upregulation of CD80 following HKE and HKE/5HT stimulation, although at a lesser extent than with LPS. Concerning CD83, the maturation induced by HKE, HKE/5HT, and LPS were comparable. For both markers, the $5 \mathrm{HT}$ treatment did not induce significant differences relative to the untreated bacteria (Figure 6A,B).

A

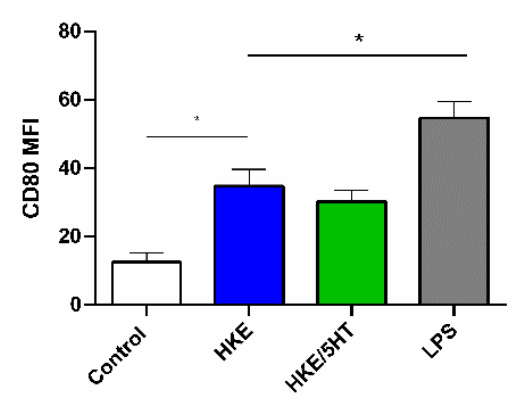

B

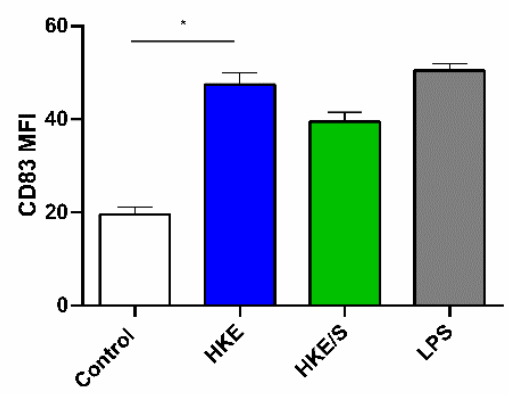

Figure 6. DC differentiation. CD80 (A) and CD83 (B) expression measured as mean fluorescence intensity (MFI), in DC untreated (Control), stimulated with LPS (positive control), or with 5HT-treated and untreated E. faecium NCIMB10415 (HKE/5HT and HKE) $\left({ }^{*} p<0.05\right)$.

\section{Discussion}

Recently, a growing interest in the microbial responses to human-derived hormones has spread in the scientific community, mainly concerning pathogenic/opportunistic bacteria [49]. In a previous paper, we evaluated the phenotypic and proteomic modifications occurring in the probiotic E. faecium NCIMB 10415 after NE stimulation [13]. In the present research, the same strain was investigated to assess which physiological parameters especially important for the probiotic potential of the strain were affected by the treatment with $50 \mu \mathrm{M}$ 5HT. We also analyzed the soluble protein profile modifications induced by the hormone, by using a cutting-edge comparative gel-free proteomic approach. The aim of the study was to ascertain if 5HT, a hormone mediating relatively different effects on human physiology [50] as compared to NE, could have similar or different effect on bacterial phenotypes.

The main findings support the following considerations: (i) E. faecium NCIMB 10415 can sense and respond to $5 \mathrm{HT}$; (ii) a better stationary phase survival and improved resistance to various stressors, including Amp, was demonstrated; (iii) 5HT can induce a higher capability of auto-aggregation and biofilm formation and a higher expression of proteins mediating bacteria-bacteria and bacteria-host interactions. However, 5HT treatment did not affect the ability of E. faecium NCIMB 10415 to induce the expression of the activation markers CD80 and CD83 on dendritic cells.

Here, we try to discuss some crucial phenotypic aspects that vary after 5HT exposure relating them to the most interesting differentially abundant proteins, by adding some comments on their physiological roles. As far as other metabolic pathways are concerned, it is difficult to assess true stimulation or negative modulation. As an example, proteomic data show that some proteins of the route for cell-wall biosynthesis are more abundant (isomerase, epimerase) whereas others (transpeptidase) are in lower amount during 5HT exposure. Similar considerations can be done for ribosomal proteins.

\subsection{HT Sensing}

Enterococcus faecium NCIMB 10415 can sense and respond to environmental 5HT as an informational molecule, and in its presence, alterations of the growth pattern were observed, together with an improved capability to auto-aggregate, to form biofilm and to survive in the presence of bile acids and Amp. It is not clear at present whether the hormone can be uptaken by the cell or rather triggers phenotypic effects by means of a surface-bound receptor. However, the finding of a higher abundance of a peculiar protein, 
the DNA-binding response regulator VicR, strongly supports the idea of the presence of a membrane sensor for 5HT in E. faecium NCIMB 10415. As a matter of fact, VicR belongs to the two-component transduction system (TCS) VicKR (YycFG), previously described in E. faecalis [51]. For the same species, other authors [52] suggested its role for sensing $\mathrm{NE}$ and modelized it by molecular docking. In general, signal transduction plays an important role in all living organisms, but it is fundamental in bacteria, which can sense rapidly changing environmental stimuli and respond accordingly. TCSs are the most spread systems allowing adaptation to environmental changes, such as variations of nutrients, communication signals, and toxic molecules [53], even if other mechanisms have been described [54]. In particular, these systems include an integral transmembrane kinase (HPK) that acts as a sensor for the stimulus and phosphorylates, and a response regulator (RR), which mediates the signaling events resulting in gene transcription and targeted expression of specific phenotypic characters in response [55]. Therefore, the greater abundance of VicR observed after $5 \mathrm{HT}$ stimulation might indicate the presence of the transmembrane VicK receptor, whose sensing domain is displayed on the E. faecium NCIMB 10415 cell surface. VicR signal transduction includes some genes critical for cell-wall biosynthesis and biofilm formation [56], in agreement with our experimental results (see next sections).

The VicKR system displays a 37\% homology with the QS-detecting system QseCB from E. coli, which also recognize nor-epinephrine as stimulus [57]. It is reasonable to hypothesize that this receptor is able to recognize hormones containing an aromatic ring, such as those derived from the amino acids tyrosine, phenylalanine, and tryptophan.

Apart from TCS, a methyl-accepting chemotaxis family protein (MCP) also proved to be more abundant after growth in 5HT. In general, MCPs are transmembrane receptors for monitoring extracellular carbohydrate concentrations. It has been suggested that, in the closely related lactic acid bacterium Streptococcus pneumoniae, the mechanism might be used to control the activity of the linked histidine kinase [58], thus strengthening the communication with the external environment. For this purpose, glutamate dehydrogenase, also involved in signal transduction [59], has been found more abundant in 5HT-stimulated conditions, suggesting that the hormone can trigger an enhanced perception of external stimuli.

\subsection{Modification of the Growth Profiles}

The influence of 5HT on bacterial growth pattern has been recently studied on several commensal strains of human GI tract [60]. However, the results are contrasting and speciesspecific. Here, we also describe that supplementation of the culture medium with 5HT affected the bacterial growth kinetics of E. faecium NCIMB 10415 in a dose-dependent manner. All of the tested concentrations of the molecule proved to be effective in enhancing the bacterial growth (Figure 1); nevertheless, $500 \mathrm{nM}$ and $50 \mu \mathrm{M}$ resulted to be the most effective, decreasing the death phase effect. This is not surprising, since hormones act at an optimal concentration level that is generally in the mean concentration range [61].

In agreement with the higher growth yield observed in stimulated cells, a higher abundance of proteins involved in DNA replication, as the DNA-directed DNA polymerase III subunit beta and the primosomal protein N, was observed in 5HT-treated E. faecium NCIMB10415 cells. Proteomic data also may suggest that the hormone enhances transport of solutes across the membrane, especially acids, amino acids, and oligopeptides, so that optimized nutrient acquisition and increased metabolism can support a certain degree of cell duplication, even in the harsh conditions of the stationary phase. The MFS family major facilitator transporter, C4-dicarboxylate porter, well characterized in both E. coli and B. subtilis [62], is responsible of the uptake of four-carbon dicarboxylic acids such as malate, fumarate, succinate, and the amino acid aspartate. This system may ensure improved carbon utilization with energy gain, which can promote better stationary phase survival. In addition, the LIVCS-family branched chain amino acid (BCAA) cation symporter is also more abundant in stimulated conditions. This symporter provides the uptake of leucine, isoleucine, and valine inside the bacterial cell using $\mathrm{Na}^{+}$or $\mathrm{H}^{+}$as co-transported ions [63]. 
The BCAAs represent about $20 \%$ of the total protein amino acids in other LAB such as $L$. lactis [64]. For bacteria that cannot synthesize them, it is very important to obtain amino acids by proteolysis and uptake [65]. We may speculate that, at the end of the logarithmic phase, BCAAs begin to be released by proteolytic action on proteins derived from dead cell autolysis. Therefore, a higher abundance of this transporter provides a higher availability of these amino acids that can favor late stationary phase growth when most nutrients are exhausted. Similar considerations can be made for a specific amino acid ABC superfamily ATP-binding cassette transporter that resulted in being 1.5 times more abundant in 5HT treatment.

The improved survival of E. faecium NCIBM 10415 during the mid and late stationary phase in stimulated conditions can also be supported by the higher abundance of proteins generating ammonia, and hence involved in $\mathrm{pH}$ buffering, such as ornithine transcarbamylase (OTC) and glutamate dehydrogenase (GDH). Indeed, they provide an enhanced resistance to acidic stress, particularly frequent when the cultures reach a stationary growth profile. In $L A B$, this mechanism is particularly efficient and ensures survival when lactic fermentation is still active by balancing acidity. In detail, ornithine transcarbamylase converts citrulline into ornithine plus carbamoyl phosphate, and belongs to the arginine deiminase pathway (ADI pathway), a route used by LAB to enhance their energy gain (ATP) and to obtain medium alkalization since two moles of ammonia are produced at each cycle [66]. Moreover, this pathway supplies building blocks for pyrimidine biosynthesis useful during DNA duplication. To this purpose, a phosphomethylpyrimidine kinase was also found more abundant after 5HT stimulation. Hence, the high abundance of the enzyme OTC under 5HT stimulation supports the idea that the hormone can enhance bacterial fitness, stimulating energy metabolism, supporting building blocks for cell duplication, and especially balancing intracellular $\mathrm{pH}$, which is very critical during the late exponential and stationary phase. In the present research under stimulated conditions, glutamate dehydrogenase (previously mentioned for its role in signal transduction), which catalyzes the degradation of glutamate to 2-oxoglutarate and ammonia, can also contribute to alkalization.

\subsection{Enhanced Resistance to Stressors}

Two paradigmatic stressing events were analyzed in addition to the commonly occurring stationary phase and oxidative stresses: survival in the presence of bile salts and antibiotics (Amp and Van).

\subsubsection{Bile Stress Resistance}

Bile is a surfactant mixture of inorganic ions, bile salts, cholesterol, and fatty acids [67], and it performs an antimicrobial activity towards gut bacteria as it can disrupt the membrane architecture by solubilizing phospholipids [68]. The genus Enterococcus is considered resistant to bile [69] and curiously, Saito and coworkers (2014) showed that E. faecalis is able to incorporate in the membranes the fatty acids from bile, enhancing its resistance to their surfactant activity and improving the membrane fluidity [70]. The proteomic results obtained in this study show after 5HT exposure a higher abundance of FakB, a protein involved in lipid incorporation into the cytoplasmic membrane. This may explain how the pretreatment with $50 \mu \mathrm{M} 5 \mathrm{HT}$ enhanced the natural tolerance of E. faecium NCIMB10415 to bile by about $20 \%$ relative to the control (Figure 3 ).

\subsubsection{Antibiotic Stress Resistance}

After 5HT exposure, enhanced Amp resistance was detected by phenotypic tests (Table 1), while no significant modifications in the sensitivity pattern were detected for Van. Amp, together with other penicillins and cephalosporins, belongs to the class of the beta-lactam antibiotics. The most common mechanisms by which bacteria develop betalactam antibiotic insensibility are the production of degrading enzymes (beta-lactamases) and the modifications of the penicillin-binding proteins (PBPs) [71]. Proteomic data seem 
to suggest that both mechanisms could be responsible of increased resistance to Amp observed after 5HT stimulation. As a matter of fact, a metal beta-lactamase (Zn-dependent hydrolase) was found in higher abundance in treated conditions. This type of hydrolase is characterized by the presence of one or two zinc atoms in the catalytic center that act as cofactors for catalysis [72], and this relates also to the higher abundance (2.1-fold change) of the CDF family cation diffusion facilitator. These integral membrane proteins mediate the uptake and extrusion of divalent cations belonging to the first and second transition series. An important number of them are involved in $\mathrm{Zn}^{++}$uptake and efflux [73]; therefore, it is possible to hypothesize a link between the overexpression of this protein and the enhanced abundance of the $\mathrm{Zn}$ beta lactamase in 5HT-stimulated conditions.

As far as the modifications of the target are concerned, the peptidyl prolyl isomerase (PrsA) proved to be in lower abundance after 5HT treatment. The PPiases are a class of foldases that support the cis/trans isomerization of the peptide bonds [74]. In particular, PrsA, a PPiase anchored to the outer side of the cytoplasmic membrane of several Grampositive bacteria, acts as a foldase of many secreted proteins $[75,76]$, including a certain class of penicillin binding proteins (PBPs) in B. subtilis [77]. A correct folding of PBPs is essential to ensure their efficient binding to the antibiotic. Therefore, the lower abundance of PrsA observed under 5HT stimulation could cause incorrect or incomplete folding of PBPs, which result is its inability to link Amp. Furthermore, a correlation between the previously noted glutamate dehydrogenase (1.4-fold more abundant after 5HT stimulation) and resistance to cell-wall targeted antibiotics has been previously observed also in $B$. subtilis [78].

\subsubsection{Stationary Phase-Related Stress}

The better survival of 5HT-stimulated cultures during the late stationary is in agreement with the concurrent enhanced abundance of the universal stress protein A, UspA, which is related to growth arrest that represents an adaptation to stationary phase conditions [79]. Actually, at this point of the growth, many stressors are present, besides nutrient depletion. In addition, since cell harvesting (for proteomic evaluation) occurred during the late exponential phase, the higher abundance of UspA in 5HT-stimulated conditions suggests that treated enterococci can anticipate the occurrence of stationary phase stress better than controls, thus improving their survival [80]. 5HT might therefore trigger the setup of an adaptive prediction on E. faecium NCIMB 10415, as previously noted in E. coli by other authors [81].

\subsubsection{Oxidative Stress}

Other two stress-counteracting proteins such as Hsp33 and thioredoxin were overexpressed after 5HT exposure. The heat shock protein Hsp33 belongs to the cellular pool of chaperones that ensure correct protein conformation and folding protection. It is also involved in misfolded proteins repair and degradation when an exogenous stressing event occurs [82]. In LAB, because of its microaerophilic nature and high sensitivity to oxygen [66], this protein is conserved among all genera to counteract oxidative stress [83]. It has been reported that Hsp33 undergoes activation during oxidative stress by the release of a Cys-bound $\mathrm{Zn}$ and formation of two disulfide bridges between Cys ${ }^{232}$ and Cys ${ }^{234}$ and $\mathrm{Cys}^{265}-\mathrm{Cys}^{268}$. In this conformation, it becomes competent for preventing protein aggregation behaving as a chaperone [84].

Thioredoxin, together with the thioredoxin reductase and the pyridine cofactor NADPH, is targeted to specifically control oxidative stress. It bears two cysteine residues, which undergo oxidation during its catalytic cycle [85].

The abundance of all these stress-counteracting proteins in stimulated conditions suggests that 5HT can induce several defense mechanisms in E. faecium NCIMB 10415 that are useful to increase physiological resistance to various stressors. 


\subsection{Better Interbacterial Interaction: Autoaggregation and Biofilm Formation}

The bacterial auto-aggregation is triggered after sensing the presence of cells belonging to the same species in the external environment. This perception leads to the formation of a substantial clump that constitutes the basal structure at the bottom of a developing ecosystem [86]. In probiotics, this cell-assembling ensures better survival in the hostile gut environment and higher protection toward the activity of the host-immune system, resulting in a longer persistence in the intestine [87]. The auto-aggregation enhancement observed in 5HT-treated bacteria (Figure 3) might be partly related to the lower abundance of PrsA in this experimental condition. Actually, previous research demonstrated that a low expression of this isomerase caused enhanced cell envelope hydrophobicity that leads to improved auto-aggregating capability in Streptococcus mutans, a strain taxonomically close to Enterococcus [88]. For the strain in study, it is worth mentioning that this protein proved to be in lower abundance also after NE treatment, in a condition in which auto-aggregation was enhanced [13], similar to what was observed in the present work.

Moreover, auto-aggregation has been described as the initial phase in the formation of biofilm [87], a cluster of bacteria living in a self-produced matrix that provides nutrient sharing and resistance to external stressors [89]. In the present investigation, the biofilm lifestyle seems to be favored in presence of 5HT (Figure 4B). This enhanced propensity to social life can be due to the increased growth yield observed after 5HT. Furthermore, the finding of a higher abundance of the oligo peptide permease OppF could relate this with quorum sensing (QS). Actually, this protein belongs to the $A B C$ transporter family (previously mentioned) and mediates the uptake of oligopeptides up to five amino acids, whatever the side chain. It is well established that biofilm formation is under QS control, and since in Gram-positive organisms QS mechanism is mediated by small peptides [90], it possible to speculate that the higher abundance of this oligopeptide transporter can favor intracellular transport of interbacterial signaling molecules. Although specific QS signals transporters are often involved, in agreement with this statement, it has been reported that oligopeptide signals are imported through $A B C$ transporters at least in the Grampositive Bacillus subtilis [91]. If this is also true for E. faecalis, as suggested by Leonard and coworkers [92], the increased abundance of these transporters might finally result in enhanced internalization of QS molecules that promote the setup of the biofilm lifestyle under 5HT effect. Furthermore, as referred in the paragraph concerning 5HT sensing, the VicKR system could also be involved in QS [57] and biofilm formation [56] that ultimately improve the bacterial resistance to the gut harsh conditions [93].

\subsection{Possible Interaction with the Host}

Evaluating the interaction of E. faecium NCIMB 10415 with the mammalian host was out of the scope of the present investigation. We limited our attention to compare the capability of 5HT-stimulated versus control bacteria to induce maturation of human dendritic cells (DC) in vitro.

Other LAB such as Lactobacilli have been shown to interact with DC and to induce strain-specific effects [94]. More specifically, activation of human and murine DCs by $E$. faecalis was demonstrated [95]. However, few data are available about the effects exerted on the immune system by E. faecium [96]. Here, we tested both living and heat-killed cells (HK) since the experiment with the living cells damaged the DCs cultures. Killed cells of $E$. faecium NCIMB 10415 displayed the ability to enhance DCs maturation (CD80 and CD83) relative to control conditions, suggesting that the DCs-activating components detected are not proteinaceous molecules that would be denatured after thermal stress. Therefore, it is possible that the observed boosting effect on DCs maturation is due to other surface components, such as lipoteichoic acids, teichoic acids, and EPS, which are not sensitive to thermal denaturation. In detail, CD80 and CD83 maturation was improved by enterococcal stimulation (both HKE and HKE/5HT) relative to control conditions (no external stimulating agent), although for CD80 this activity was not as efficient as that triggered by LPS stimulation (Figure 6A,B). This is reasonable since the E. faecium NCIMB 10415 is a 
probiotic strain, whereas LPS is generally derived from pathogenic Gram-negative bacteria. When specifically considering their biological functions, both CD80 and CD83 relate to T lymphocytes activation. In the literature, experiments describing the effects of probiotic $E$. faecium strains on the host immune system only refer to increased neutrophil phagocytosis and humoral immunity [96]. Therefore, no comparison with known data is possible. Even if 5HT-treated enterococci seemed to be slightly less effective in inducing DC maturation than untreated bacteria, the difference observed is not statistically significant. Hence, further experiments are necessary to better assess the effect of 5HT on the microbiota-immune system axis.

These results on the potential immune-modulating effects of $\mathrm{HKE}$ and $\mathrm{HKE} / 5 \mathrm{HT}$ suggest that the light immune-stimulating capabilities of this probiotic are not so deeply altered by $5 \mathrm{HT}$ exposure. However, $5 \mathrm{HT}$ also triggers other modifications on the bacterial phenotype that can affect the overall host-bacteria interactions. Among these modifications, those improving microbial adhesion are worth discussion. Actually, some proteins displaying moonlight function (moonlight proteins, MPs) and involved in host interaction have been found in higher abundance after 5HT treatment. MPs perform more than one role in different cell compartments [97]. Generally, in bacteria, housekeeping enzymes when secreted can act both as adhesins for host tissues and as immune stimulators. Among MPs, pyruvate dehydrogenase is a multimeric moonlighting enzyme whose subunits can interact with the host extracellular matrix components, such as fibronectin, as described in Lactobacillus plantarum [98]. The alpha subunit of the E1 component (PDHA), here found more abundant in 5HT-treated cultures, was demonstrated to bind plasminogen in a study concerning Mycoplasma gallisepticum [99]. This component has also been referred to as one of the main immunogenic proteins in Streptococcus, since it displayed the capability to induce antibody production in fish [100]. It is reasonable to assume that exposure of this protein on the bacterial surface could mediate these immunogenic effects. Here, we did not evaluate antibody production and we did not detect significant differences in DCs maturation elicited by treated vs. untreated cultures. However, it is possible that the alpha subunit of the E1 component (PDHA), here overexpressed, is not present in the HKE samples, because it undergoes denaturation following the thermal treatment, as previously reported.

Among the MPs found in higher abundance in stimulated cultures, phosphoglycerate mutase (PGM) is a central metabolism enzyme displaying the highest variation in treated and control cultures (2.4-fold change). It is a glycolytic/gluconeogenetic enzyme with moonlighting behavior in Bifidobacterium lactis BI07 and Lactococcus lactis [101,102], whose additional role is plasminogen binding. A second protein specifically binding the extracellular matrix protein fibronectin is the ornithine transcarbamylase (already mentioned as buffering agent), a moonlighting enzyme described as an adhesin in the nonpathogenic Staphylococcus epidermidis [103], but also as immune-stimulating antigen as reported in Clostridium perfringens by Alam et al. [104]. Further experiments intended to assess possible enhanced adhesion to mammalian tissues and immune cells after 5HT treatment are necessary to prove the significance of these findings.

\section{Conclusions}

Taken together, the overall results obtained in the present research on E. faecium NCIMB 10415 after 5HT stimulation reveal some similarities and some differences with previous data obtained with the same strain after NE treatment [13]. In detail, better survival during the stationary phase, enhanced resistance to bile salts, and improved aptitude to form biofilm and to auto-aggregate, all detected here, were also triggered by NE treatment.

Among the stress-counteracting responses specifically induced by $5 \mathrm{HT}$, is worth noting an increased resistance to Amp, probably mediated by enhanced transcription of Zn-dependent beta lactamase, but also by altered folding of PBPs. Moreover, some proteins 
attenuating stationary phase stress (UspA), oxidative stress (Hsp33, thioredoxin), and $\mathrm{pH}$-related stress (OTC, GD) were more abundant after 5HT treatment.

In general, the proteomic data suggest a stronger effect of $5 \mathrm{HT}$, since the protein fold changes were higher than those reported after NE stimulation. Furthermore, the induction of a possible hormone sensor VicK, involved in QS peptides perception as well, absent after NE stimulation, was suggested by the presence of its cognate RR VicR, in the present study.

To conclude, it is interesting to underline that while in E. faecium NCIMB $10415 \mathrm{NE}$ and 5HT trigger similar (although not identical) effects, in the human host they often behave differently, inducing opposite reactions. Actually, at a systemic level, NE triggers stress responses, whereas 5HT induces relaxation, mood improvement, and stress adaptation [1]. However, it must be highlighted that in humans, at the gut level, negative effects can also be mediated by high levels of 5HT, similar to what occurs with NE [27]. Here, both NE and $5 \mathrm{HT}$ seem to go in the direction of improving environmental resistance of the strain, thus ensuring that its probiotic effect can be better achieved in the gut, whatever the stimulating molecule present in this context. In this respect, $5 \mathrm{HT}$ proves to better enhance the fitness of E. faecium NCIMB 10415 than NE. Since in the literature data concerning the effects of human hormones on probiotic bacteria are scarce, this report can constitute a valuable starting point to assess probiotic efficacy in the fast-changing conditions present in the human gut.

Supplementary Materials: The following are available online at https:/ / www.mdpi.com/article/ 10.3390/microbiolres12030043/s1, SM1: CDM composition; SM2: proteomic results, SM3: OD $24 \mathrm{~h}$ table; CFU counting.

Author Contributions: R.S.: conceptualization, investigation, data curation, writing-original draft, methodology, validation, visualization, and formal analysis. M.M. and E.B.: methodology, software, and validation. S.S.: investigation and visualization. E.M.: data curation and supervision. E.P.: conceptualization, supervision, writing, reviewing, editing, project administration, and funding. All authors have read and agreed to the published version of the manuscript.

Funding: This work has been supported by Ricerca locale 2019-2020 of University of Turin and PhD funding.

Data Availability Statement: Mass spectrometry proteomics data are deposited in the ProteomeXchange Consortium by the PRIDE partner repository (https:/ /www.ebi.ac.uk/pride/archive/, accessed on 7 January 2021) with the dataset identifier PXD023456.

Acknowledgments: The authors are grateful to Roberto Mazzoli for helping during the restyling of the manuscript and to Cinzia Bertea for supplying laboratory material necessary to complete the study.

Conflicts of Interest: The authors declare no conflict of interest.

\section{References}

1. Mazzoli, R.; Pessione, E. The Neuro-endocrinological Role of Microbial Glutamate and GABA Signaling. Front. Microbiol. 2016, 7. [CrossRef]

2. Lyte, M. Microbial Endocrinology: Interkingdom Signaling in Infectious Disease and Health; Springer International Publishing: Cham, Germany, 2016. [CrossRef]

3. Segain, J.-P. Butyrate inhibits inflammatory responses through NFkappa B inhibition: Implications for Crohn's disease. Gut 2000, 47,397-403. [CrossRef] [PubMed]

4. Cryan, J.F.; Dinan, T.G. Mind-altering microorganisms: The impact of the gut microbiota on brain and behaviour. Nat. Rev. Neurosci. 2012, 13, 701-712. [CrossRef] [PubMed]

5. Mazzoli, R.; Pessione, E.; Dufour, M.; Laroute, V.; Giuffrida, M.G.; Giunta, C.; Cocaign-Bousquet, M.; Loubière, P. Glutamateinduced metabolic changes in Lactococcus lactis NCDO 2118 during GABA production: Combined transcriptomic and proteomic analysis. Amino Acids 2010, 39, 727-737. [CrossRef]

6. Richard, H.; Foster, J.W. Escherichia coli Glutamate- and Arginine-Dependent Acid Resistance Systems Increase Internal pH and Reverse Transmembrane Potential. J. Bacteriol. 2004, 186, 6032-6041. [CrossRef] [PubMed]

7. Lyte, M. Probiotics function mechanistically as delivery vehicles for neuroactive compounds: Microbial endocrinology in the design and use of probiotics. BioEssays 2011, 33, 574-581. [CrossRef] 
8. RWong, K.; Yang, C.; Song, G.-H.; Wong, J.; Ho, K.-Y. Melatonin Regulation as a Possible Mechanism for Probiotic (VSL\#3) in Irritable Bowel Syndrome: A Randomized Double-Blinded Placebo Study. Dig. Dis. Sci. 2015, 60, 186-194. [CrossRef]

9. Norris, V.; Molina, F.; Gewirtz, A.T. Hypothesis: Bacteria Control Host Appetites. J. Bacteriol. 2013, 195, 411-416. [CrossRef]

10. Masek, K.; Kadlec, O. Sleep factor, muramyl peptides, and the serotoninergic system. Lancet 1983, 1, 1277. [CrossRef] [PubMed]

11. Özoğul, F. Production of biogenic amines by Morganella morganii, Klebsiella pneumoniae and Hafnia alvei using a rapid HPLC method. Eur. Food Res. Technol. 2004, 219, 465-469. [CrossRef]

12. Sandrini, S.; Alghofaili, F.; Freestone, P.; Yesilkaya, H. Host stress hormone norepinephrine stimulates pneumococcal growth, biofilm formation and virulence gene expression. BMC Microbiol. 2014, 14, 180. [CrossRef]

13. Scardaci, R.; Varese, F.; Manfredi, M.; Marengo, E.; Mazzoli, R.; Pessione, E. Enterococcus faecium NCIMB10415 responds to norepinephrine by altering protein profiles and phenotypic characters. J. Proteom. 2021, 231, 104003. [CrossRef]

14. Yang, Q.; Anh, N.D.Q.; Bossier, P.; Defoirdt, T. Norepinephrine and dopamine increase motility, biofilm formation, and virulence of Vibrio harveyi. Front. Microbiol. 2014, 5, 584. [CrossRef]

15. Cogan, T.A.; Thomas, A.O.; Rees, L.E.N.; Taylor, A.H.; Jepson, M.A.; Williams, P.H.; Ketley, J.; Humphrey, T.J. Norepinephrine increases the pathogenic potential of Campylobacter jejuni. Gut 2007, 56, 1060-1065. [CrossRef]

16. Hiller, C.C.; Lucca, V.; Carvalho, D.; Borsoi, A.; Borges, K.A.; Furian, T.Q.; do Nascimento, V.P. Influence of catecholamines on biofilm formation by Salmonella Enteritidis. Microb. Pathog. 2019, 130, 54-58. [CrossRef] [PubMed]

17. Halang, P.; Toulouse, C.; Geißel, B.; Michel, B.; Flauger, B.; Müller, M.; Voegele, R.T.; Stefanski, V.; Steuber, J. Response of Vibrio cholerae to the Catecholamine Hormones Epinephrine and Norepinephrine. J. Bacteriol. 2015, 197, 3769-3778. [CrossRef] [PubMed]

18. Paulose, J.K.; Wright, J.M.; Patel, A.G.; Cassone, V.M. Human Gut Bacteria Are Sensitive to Melatonin and Express Endogenous Circadian Rhythmicity. PLoS ONE 2016, 11, e0146643. [CrossRef]

19. Biaggini, K.; Barbey, C.; Borrel, V.; Feuilloley, M.; Déchelotte, P.; Connil, N. The pathogenic potential of Pseudomonas fluorescens MFN1032 on enterocytes can be modulated by serotonin, substance P and epinephrine. Arch. Microbiol. 2015, 197, 983-990. [CrossRef] [PubMed]

20. O'Mahony, S.M.; Clarke, G.; Borre, Y.E.; Dinan, T.G.; Cryan, J.F. Serotonin, tryptophan metabolism and the brain-gut-microbiome axis. Behav. Brain Res. 2015, 277, 32-48. [CrossRef]

21. Galligan, J.J. Beneficial actions of microbiota-derived tryptophan metabolites. Neurogastroenterol. Motil. 2018, 30 , e13283. [CrossRef]

22. Yanofsky, C. RNA-based regulation of genes of tryptophan synthesis and degradation, in bacteria. RNA 2007, 13, 1141-1154. [CrossRef]

23. Raboni, S.; Bettati, S.; Mozzarelli, A. Tryptophan synthase: A mine for enzymologists. Cell. Mol. Life Sci. 2009, 66, 2391-2403. [CrossRef]

24. Krishnan, S.; Ding, Y.; Saedi, N.; Choi, M.; Sridharan, G.V.; Sherr, D.H.; Yarmush, M.L.; Alaniz, R.C.; Jayaraman, A.; Lee, K. Gut Microbiota-Derived Tryptophan Metabolites Modulate Inflammatory Response in Hepatocytes and Macrophages. Cell Rep. 2018, 23, 1099-1111. [CrossRef]

25. Matur, E.; Eraslan, E. The Impact of Probiotics on the Gastrointestinal Physiology. In New Advances in the Basic and Clinical Gastroenterology; Brzozowski, T., Ed.; IntechOpen: London, UK, 2012. [CrossRef]

26. Özoğul, F.; Kuley, E.; Özoğul, Y.; Özoğul, İ. The Function of Lactic Acid Bacteria on Biogenic Amines Production by Food-Borne Pathogens in Arginine Decarboxylase Broth. Food Sci. Technol. Res. 2012, 18, 795-804. [CrossRef]

27. Manocha, M.; Khan, W.I. Serotonin and GI Disorders: An Update on Clinical and Experimental Studies. Clin. Transl. Gastroenterol. 2012, 3, e13. [CrossRef]

28. Kumar, A.; Russell, R.M.; Pifer, R.; Menezes-Garcia, Z.; Cuesta, S.; Narayanan, S.; MacMillan, J.B.; Sperandio, V. The Serotonin Neurotransmitter Modulates Virulence of Enteric Pathogens. Cell Host Microbe 2020, 28, 41-53.e8. [CrossRef] [PubMed]

29. Hanchi, H.; Mottawea, W.; Sebei, K.; Hammami, R. The Genus Enterococcus: Between Probiotic Potential and Safety ConcernsAn Update. Front. Microbiol. 2018, 9. [CrossRef]

30. Otto, R.; Brink, B.; Veldkamp, H.; Konings, W.N. The relation between growth rate and electrochemical proton gradient of Streptococcus cremoris. FEMS Microbiol. Lett. 1983, 16, 69-74. [CrossRef]

31. Poolman, B.; Konings, W.N. Relation of growth of Streptococcus lactis and Streptococcus cremoris to amino acid transport. J. Bacteriol. 1988, 170, 700-707. [CrossRef]

32. Zommiti, M.; Cambronel, M.; Maillot, O.; Barreau, M.; Sebei, K.; Feuilloley, M.; Ferchichi, M.; Connil, N. Evaluation of Probiotic Properties and Safety of Enterococcus faecium Isolated From Artisanal Tunisian Meat "Dried Ossban". Front. Microbiol. 2018, 9. [CrossRef] [PubMed]

33. Baccouri, O.; Boukerb, A.M.; Farhat, L.B.; Zébré, A.; Zimmermann, K.; Domann, E.; Cambronel, M.; Barreau, M.; Maillot, O.; Rincé, I.; et al. Probiotic Potential and Safety Evaluation of Enterococcus faecalis OB14 and OB15, Isolated From Traditional Tunisian Testouri Cheese and Rigouta, Using Physiological and Genomic Analysis. Front. Microbiol. 2019, 10. [CrossRef] [PubMed]

34. O’Toole, G.A. Microtiter Dish Biofilm Formation Assay. J. Vis. Exp. 2011. [CrossRef] [PubMed]

35. Pessione, E.; Mazzoli, R.; Giuffrida, M.G.; Lamberti, C.; Garcia-Moruno, E.; Barello, C.; Conti, A.; Giunta, C. A proteomic approach to studying biogenic amine producing lactic acid bacteria. Proteomics 2005, 5, 687-698. [CrossRef] 
36. Pessione, E.; Pessione, A.; Lamberti, C.; Coïsson, D.J.; Riedel, K.; Mazzoli, R.; Bonetta, S.; Eberl, L.; Giunta, C. First evidence of a membrane-bound, tyramine and $\beta$-phenylethylamine producing, tyrosine decarboxylase in Enterococcus faecalis: A twodimensional electrophoresis proteomic study. Proteomics 2009, 9, 2695-2710. [CrossRef]

37. Wessel, D.M.; Flügge, U.I. A method for the quantitative recovery of protein in dilute solution in the presence of detergents and lipids. Anal. Biochem. 1984, 138, 141-143. [CrossRef]

38. Collins, B.C.; Hunter, C.L.; Liu, Y.; Schilling, B.; Rosenberger, G.; Bader, S.L.; Chan, D.W.; Gibson, B.W.; Gingras, A.-C.; Held, J.M.; et al. Multi-laboratory assessment of reproducibility, qualitative and quantitative performance of SWATH-mass spectrometry. Nat. Commun. 2017, 8, 291. [CrossRef]

39. Ludwig, C.; Gillet, L.; Rosenberger, G.; Amon, S.; Collins, B.C.; Aebersold, R. Data-independent acquisition-based SWATH-MS for quantitative proteomics: A tutorial. Mol. Syst. Biol. 2018, 14. [CrossRef] [PubMed]

40. Usai, G.; Cirrincione, S.; Re, A.; Manfredi, M.; Pagnani, A.; Pessione, E.; Mazzoli, R. Clostridium cellulovorans metabolism of cellulose as studied by comparative proteomic approach. J. Proteom. 2020, 216, 103667. [CrossRef]

41. Pozza, E.D.; Manfredi, M.; Brandi, J.; Buzzi, A.; Conte, E.; Pacchiana, R.; Cecconi, D.; Marengo, E.; Donadelli, M. Trichostatin A alters cytoskeleton and energy metabolism of pancreatic adenocarcinoma cells: An in depth proteomic study. J. Cell. Biochem. 2018, 119, 2696-2707. [CrossRef]

42. Martinotti, S.; Patrone, M.; Manfredi, M.; Gosetti, F.; Pedrazzi, M.; Marengo, E.; Ranzato, E. HMGB1 Osteo-Modulatory Action on Osteosarcoma SaOS-2 Cell Line: An Integrated Study From Biochemical and -Omics Approaches. J. Cell. Biochem. 2016, 117, 2559-2569. [CrossRef] [PubMed]

43. Carbonare, L.D.; Manfredi, M.; Caviglia, G.; Conte, E.; Robotti, E.; Marengo, E.; Cheri, S.; Zamboni, F.; Gabbiani, D.; Deiana, M.; et al. Can half-marathon affect overall health? The yin-yang of sport. J. Proteom. 2018, 170, 80-87. [CrossRef]

44. Albanese, P.; Manfredi, M.; Meneghesso, A.; Marengo, E.; Saracco, G.; Barber, J.; Morosinotto, T.; Pagliano, C. Dynamic reorganization of photosystem II supercomplexes in response to variations in light intensities. Biochim. Biophys. Acta (BBA) Bioenerg. 2016, 1857, 1651-1660. [CrossRef]

45. Perez-Riverol, Y.; Csordas, A.; Bai, J.; Bernal-Llinares, M.; Hewapathirana, S.; Kundu, D.J.; Inuganti, A.; Griss, J.; Mayer, G.; Eisenacher, M.; et al. The PRIDE database and related tools and resources in 2019: Improving support for quantification data. Nucleic Acids Res. 2019, 47, D442-D450. [CrossRef] [PubMed]

46. Huerta-Cepas, J.; Szklarczyk, D.; Forslund, K.; Cook, H.; Heller, D.; Walter, M.C.; Rattei, T.; Mende, D.R.; Sunagawa, S.; Kuhn, M.; et al. eggNOG 4.5: A hierarchical orthology framework with improved functional annotations for eukaryotic, prokaryotic and viral sequences. Nucleic Acids Res. 2016, 44, D286-D293. [CrossRef]

47. Tatusov, R.L.; Koonin, E.V. A genomic perspective on protein families.(cover story). Science 1997, 278, 631-637. [CrossRef]

48. Qin, X.; Galloway-Peña, J.R.; Sillanpaa, J.; Roh, J.H.; Nallapareddy, S.R.; Chowdhury, S.; Bourgogne, A.; Choudhury, T.; Muzny, D.M.; Buhay, C.J.; et al. Complete genome sequence of Enterococcus faecium strain TX16 and comparative genomic analysis of Enterococcus faecium genomes. BMC Microbiol. 2012, 12, 135. [CrossRef] [PubMed]

49. Cambronel, M.; Tortuel, D.; Biaggini, K.; Maillot, O.; Taupin, L.; Réhel, K.; Rincé, I.; Muller, C.; Hardouin, J.; Feuilloley, M.; et al. Epinephrine affects motility, and increases adhesion, biofilm and virulence of Pseudomonas aeruginosa H103. Sci. Rep. 2019, 9. [CrossRef] [PubMed]

50. Mohammad-Zadeh, L.F.; Moses, L.; Gwaltney-Brant, S.M. Serotonin: A review. J. Vet. Pharmacol. Ther. 2008, 31, 187-199. [CrossRef]

51. Hancock, L.; Perego, M. Two-Component Signal Transduction in Enterococcus faecalis. J. Bacteriol. 2002, 184, 5819-5825. [CrossRef]

52. Cambronel, M.; Nilly, F.; Mesguida, O.; Boukerb, A.M.; Racine, P.-J.; Baccouri, O.; Borrel, V.; Martel, J.; Fécamp, F.; Knowlton, R.; et al. Influence of Catecholamines (Epinephrine/Norepinephrine) on Biofilm Formation and Adhesion in Pathogenic and Probiotic Strains of Enterococcus faecalis. Front. Microbiol. 2020, 11. [CrossRef]

53. Pinto, D.; Mascher, T. (Actino)Bacterial "intelligence": Using comparative genomics to unravel the information processing capacities of microbes. Curr. Genet. 2016, 62, 487-498. [CrossRef] [PubMed]

54. Lyon, P. The cognitive cell: Bacterial behavior reconsidered. Front. Microbiol. 2015, 6. [CrossRef]

55. Stock, A.M.; Robinson, V.L.; Goudreau, P.N. Two-Component Signal Transduction. Ann. Rev. Biochem. 2000, 69, 183-215. [CrossRef]

56. Senadheera, M.D.; Guggenheim, B.; Spatafora, G.A.; Huang, Y.-C.C.; Choi, J.; Hung, D.C.I.; Treglown, J.S.; Goodman, S.D.; Ellen, R.P.; Cvitkovitch, D.G. A VicRK Signal Transduction System in Streptococcus mutans Affects gtfBCD, gbpB, and ftf Expression, Biofilm Formation, and Genetic Competence Development. J. Bacteriol. 2005, 187, 4064-4076. [CrossRef]

57. Clarke, M.B.; Hughes, D.T.; Zhu, C.; Boedeker, E.C.; Sperandio, V. The QseC sensor kinase: A bacterial adrenergic receptor. Proc. Natl. Acad. Sci. USA 2006, 103, 10420-10425. [CrossRef]

58. Lange, R.; Wagner, C.; de Saizieu, A.; Flint, N.; Molnos, J.; Stieger, M.; Caspers, P.; Kamber, M.; Keck, W.; Amrein, K.E. Domain organization and molecular characterization of 13 two-component systems identified by genome sequencing of Streptococcus pneumoniae. Gene 1999, 237, 223-234. [CrossRef]

59. Gunka, K.; Newman, J.A.; Commichau, F.M.; Herzberg, C.; Rodrigues, C.; Hewitt, L.; Lewis, R.J.; Stülke, J. Functional Dissection of a Trigger Enzyme: Mutations of the Bacillus subtilis Glutamate Dehydrogenase RocG That Affect Differentially Its Catalytic Activity and Regulatory Properties. J. Mol. Biol. 2010, 400, 815-827. [CrossRef] 
60. Kwon, Y.H.; Wang, H.; Denou, E.; Ghia, J.-E.; Rossi, L.; Fontes, M.E.; Bernier, S.P.; Shajib, M.S.; Banskota, S.; Collins, S.M.; et al. Modulation of Gut Microbiota Composition by Serotonin Signaling Influences Intestinal Immune Response and Susceptibility to Colitis. Cell. Mole. Gastroenterol. Hepatol. 2019, 7, 709-728. [CrossRef]

61. Ganong, W.F. Review of Medical Physiology; Mcgraw-Hill: New York, NY, USA, 1995.

62. Alvarado, A.; Behrens, W.; Josenhans, C. Protein Activity Sensing in Bacteria in Regulating Metabolism and Motility. Front. Microbiol. 2020, 10. [CrossRef] [PubMed]

63. Saier, M.H., Jr. Families of transmembrane transporters selective for amino acids and their derivatives The information presented in this review was initially prepared for presentation at the FASEB meeting on amino acid transport held in Copper Mountain, Colorado, June 26-July 1, 1999 and was updated in January 2000 following the meeting of the Transport Nomenclature Panel of the International Union of Biochemistry and Molecular Biology (IUBMB) in Geneva, November 28-30, 1999. The system of classification described in this review reflects the recommendations of that panel. Microbiology 2000, 146, 1775-1795. [CrossRef] [PubMed]

64. Mills, O.E.; Thomas, T.D. Nitrogen sources for growth of lactic streptococci in milk. N. Z. J. Dairy Sci. Technol. 1981, $16,43-45$.

65. Garault, P.; Letort, C.; Juillard, V.; Monnet, V. Branched-Chain Amino Acid Biosynthesis Is Essential for Optimal Growth of Streptococcus thermophilus in Milk. Appl. Environ. Microbiol. 2000, 66, 5128-5133. [CrossRef] [PubMed]

66. Pessione, E. Lactic acid bacteria contribution to gut microbiota complexity: Lights and shadows. Front. Cell. Infect. Microbiol. 2012, 2. [CrossRef]

67. KBarrett, E.; Ganong, W.F. Ganong's Review of Medical Physiology, 24th ed.; McGraw-Hill Med: New York, NY, USA, 2012.

68. Merritt, M.E.; Donaldson, J.R. Effect of bile salts on the DNA and membrane integrity of enteric bacteria. J. Med. Microbiol. 2009, 58, 1533-1541. [CrossRef]

69. Breton, Y.L.; Mazé, A.; Hartke, A.; Lemarinier, S.; Auffray, Y.; Rincé, A. Isolation and Characterization of Bile Salts-Sensitive Mutants of Enterococcus faecalis. Curr. Microbiol. 2002, 45, 0434-0439. [CrossRef] [PubMed]

70. HSaito, E.; Harp, J.R.; Fozo, E.M. Incorporation of Exogenous Fatty Acids Protects Enterococcus faecalis from MembraneDamaging Agents. Appl. Environ. Microbiol. 2014, 80, 6527-6538. [CrossRef]

71. Andersen, B.M. Bacterial resistance against beta-lactam antibiotics. Tidsskr. Nor. Laegeforen 1990, 110, $3233-3239$.

72. Sacha, P.; Wieczorek, P.; Hauschild, T.; Zórawski, M.; Olszańska, D.; Tryniszewska, E. Metallo-beta-lactamases of Pseudomonas aeruginosa-a novel mechanism resistance to beta-lactam antibiotics. Folia Histochem. Cytobiol. 2008, 46. [CrossRef] [PubMed]

73. Anton, A.; Weltrowski, A.; Haney, C.J.; Franke, S.; Grass, G.; Rensing, C.; Nies, D.H. Characteristics of Zinc Transport by Two Bacterial Cation Diffusion Facilitators from Ralstonia metallidurans CH34 and Escherichia coli. J. Bacteriol. 2004, 186, 7499-7507. [CrossRef]

74. Schiene, C.; Fischer, G. Enzymes that catalyse the restructuring of proteins. Curr. Opin. Struct. Biol. 2000, 10, 40-45. [CrossRef]

75. Kontinen, V.P.; Sarvas, M. The PrsA lipoprotein is essential for protein secretion in Bacillus subtilis and sets a limit for high-level secretion. Mol. Microbiol. 1993, 8, 727-737. [CrossRef] [PubMed]

76. Lindholm, A.; Ellmén, U.; Tolonen-Martikainen, M.; Palva, A. Heterologous protein secretion in Lactococcus lactis is enhanced by the Bacillus subtilis chaperone-like protein PrsA. Appl. Microbiol. Biotechnol. 2006, 73, 904-914. [CrossRef] [PubMed]

77. Hyyryläinen, H.-L.; Marciniak, B.C.; Dahncke, K.; Pietiäinen, M.; Courtin, P.; Vitikainen, M.; Seppala, R.; Otto, A.; Becher, D.; Chapot-Chartier, M.-P.; et al. Penicillin-binding protein folding is dependent on the PrsA peptidyl-prolyl cis-trans isomerase in Bacillus subtilis. Mol. Microbiol. 2010, 77, 108-127. [CrossRef] [PubMed]

78. Lee, Y.H.; Kingston, A.W.; Helmann, J.D. Glutamate Dehydrogenase Affects Resistance to Cell Wall Antibiotics in Bacillus subtilis. J. Bacteriol. 2012, 194, 993-1001. [CrossRef] [PubMed]

79. Freestone, P.; Nyström, T.; Trinei, M.; Norris, V. The universal stress protein, UspA, of Escherichia coli is phosphorylated in response to stasis. J. Mol. Biol. 1997, 274, 318-324. [CrossRef]

80. Goo, E.; Majerczyk, C.D.; An, J.H.; Chandler, J.R.; Seo, Y.-S.; Ham, H.; Lim, J.Y.; Kim, H.; Lee, B.; Jang, M.S.; et al. Bacterial quorum sensing, cooperativity, and anticipation of stationary-phase stress. Proc. Natl. Acad. Sci. USA 2012, 109, 19775-19780. [CrossRef]

81. Mitchell, A.; Romano, G.H.; Groisman, B.; Yona, A.; Dekel, E.; Kupiec, M.; Dahan, O.; Pilpel, Y. Adaptive prediction of environmental changes by microorganisms. Nature 2009, 460, 220-224. [CrossRef]

82. Maleki, F.; Khosravi, A.; Nasser, A.; Taghinejad, H.; Azizian, M. Bacterial Heat Shock Protein Activity. J. Clin. Diagn Res. 2016, 10, BE01-BE03. [CrossRef]

83. Sugimoto, S.; Abdullah-Al-Mahin; Sonomoto, K. Molecular Chaperones in Lactic Acid Bacteria: Physiological Consequences and Biochemical Properties. J. Biosci. Bioeng. 2008, 106, 324-336. [CrossRef] [PubMed]

84. Graumann, J.; Lilie, H.; Tang, X.; Tucker, K.A.; Hoffmann, J.H.; Vijayalakshmi, J.; Saper, M.; Bardwell, J.C.A.; Jakob, U. Activation of the Redox-Regulated Molecular Chaperone Hsp33-A Two-Step Mechanism. Structure 2001, 9, 377-387. [CrossRef]

85. Holmgren, A.; Bjornstedt, M. Thioredoxin and thioredoxin reductase. In Methods in Enzymology; Elsevier: Amsterdam, The Netherlands, 1995; pp. 199-208. [CrossRef]

86. MCollado, C.; Meriluoto, J.; Salminen, S. Adhesion and aggregation properties of probiotic and pathogen strains. Eur. Food Res. Technol. 2008, 226, 1065-1073. [CrossRef]

87. Trunk, T.; Khalil, H.S.; Leo, J.C. Bacterial Cell Surface Group, Section for Genetics and Evolutionary Biology, Department of Biosciences, University of Oslo, Oslo, Norway, Bacterial autoaggregation. AIMS Microbiol. 2018, 4, 140-164. [CrossRef] 
88. Guo, L.; Wu, T.; Hu, W.; He, X.; Sharma, S.; Webster, P.; Gimzewski, J.K.; Zhou, X.; Lux, R.; Shi, W. Phenotypic characterization of the foldase homologue PrsA in Streptococcus mutans. Mol. Oral Microbiol. 2013, 28, 154-165. [CrossRef]

89. Costerton, J. Overview of microbial biofilms. J. Ind. Microbiol. 1995, 15, 137-140. [CrossRef]

90. Monnet, V.; Gardan, R. Quorum-sensing regulators in Gram-positive bacteria: 'cherchez le peptide': Quorum-sensing regulators in Gram-positive bacteria. Mol. Microbiol. 2015, 97, 181-184. [CrossRef] [PubMed]

91. Visick, K.L.; Fuqua, C. Decoding Microbial Chatter: Cell-Cell Communication in Bacteria. J. Bacteriol. 2005, 187, 5507-5519. [CrossRef] [PubMed]

92. Leonard, B.A.; Podbielski, A.; Hedberg, P.J.; Dunny, G.M. Enterococcus faecalis pheromone binding protein, PrgZ, recruits a chromosomal oligopeptide permease system to import sex pheromone cCF10 for induction of conjugation. Proc. Natl. Acad. Sci. USA 1996, 93, 260-264. [CrossRef]

93. Salas-Jara, M.; Ilabaca, A.; Vega, M.; García, A. Biofilm Forming Lactobacillus: New Challenges for the Development of Probiotics. Microorganisms 2016, 4, 35. [CrossRef] [PubMed]

94. Meijerink, M.; van Hemert, S.; Taverne, N.; Wels, M.; de Vos, P.; Bron, P.A.; Savelkoul, H.F.; van Bilsen, J.; Kleerebezem, M.; Wells, J.M. Identification of Genetic Loci in Lactobacillus plantarum That Modulate the Immune Response of Dendritic Cells Using Comparative Genome Hybridization. PLoS ONE 2010, 5, e10632. [CrossRef] [PubMed]

95. Molina, M.A.; Díaz, A.M.; Hesse, C.; Ginter, W.; Gentilini, M.V.; Nuñez, G.G.; Canellada, A.M.; Sparwasser, T.; Berod, L.; Castro, M.S.; et al. Immunostimulatory Effects Triggered by Enterococcus faecalis CECT7121 Probiotic Strain Involve Activation of Dendritic Cells and Interferon-Gamma Production. PLoS ONE 2015, 10, e0127262. [CrossRef]

96. Khalkhali, S.; Mojgani, N. Enterococcus faecium; a Suitable Probiotic Candidate for Modulation of Immune Responses against Pathogens. Int. J. Basic Sci. Med. 2017, 2, 77-82. [CrossRef]

97. Jeffery, C.J. Moonlighting proteins-An update. Mol. BioSyst. 2009, 5, 345. [CrossRef] [PubMed]

98. Vastano, V.; Salzillo, M.; Siciliano, R.A.; Muscariello, L.; Sacco, M.; Marasco, R. The E1 beta-subunit of pyruvate dehydrogenase is surface-expressed in Lactobacillus plantarum and binds fibronectin. Microbiol. Res. 2014, 169, 121-127. [CrossRef]

99. Qi, J.; Zhang, F.; Wang, Y.; Liu, T.; Tan, L.; Wang, S.; Tian, M.; Li, T.; Wang, X.; Ding, C.; et al. Characterization of Mycoplasma gallisepticum pyruvate dehydrogenase alpha and beta subunits and their roles in cytoadherence. PLoS ONE 2018, 13, e0208745. [CrossRef]

100. Sheng, X.; Liu, M.; Liu, H.; Tang, X.; Xing, J.; Zhan, W. Identification of immunogenic proteins and evaluation of recombinant PDHA1 and GAPDH as potential vaccine candidates against Streptococcus iniae infection in flounder (Paralichthys olivaceus). PLoS ONE 2018, 13, e0195450. [CrossRef]

101. Candela, M.; Bergmann, S.; Vici, M.; Vitali, B.; Turroni, S.; Eikmanns, B.J.; Hammerschmidt, S.; Brigidi, P. Binding of Human Plasminogen to Bifidobacterium. J. Bacteriol. 2007, 189, 5929-5936. [CrossRef]

102. Genovese, F.; Coïsson, J.D.; Majumder, A.; Pessione, A.; Svensson, B.; Jacobsen, S.; Pessione, E. An exoproteome approach to monitor safety of a cheese-isolated Lactococcus lactis. Food Res. Int. 2013, 54, 1072-1079. [CrossRef]

103. Hussain, M.; Peters, G.; Chhatwal, G.S.; Herrmann, M. A lithium chloride-extracted, broad-spectrum-adhesive 42-kilodalton protein of Staphylococcus epidermidis is ornithine carbamoyltransferase. Infect. Immun. 1999, 67, 6688-6690. [CrossRef] [PubMed]

104. Alam, S.; Bansod, S.; Kumar, R.; Sengupta, N.; Singh, L. Differential proteomic analysis of Clostridium perfringens ATCC13124; identification of dominant, surface and structure associated proteins. BMC Microbiol. 2009, 9, 162. [CrossRef] [PubMed] 